\title{
УДК 528:489
}

\author{
Н. ЛАЗОРЕНКО-ГЕВЕЛЬ ${ }^{1}$, Ю. КАРПІНСЬКИЙ ${ }^{2}$, Д. КІНЬ $^{1}$
}

\author{
${ }^{1}$ Кафедра геоінформатики і фотограмметрії, Київський національний університет будівництва і архітектури, Повітрофлотський \\ проспект, 31, Київ, 03037, Україна, e-mail: nadiialg@gmail.com, kondanil@gmail.com \\ ${ }^{2}$ Науково-дослідний інститут геодезії і картографії, вул. Велика Васильківська, 69, Київ, 03150, Україна, е-таil: \\ karp@gki.com.ua
}

\section{ОСОБЛИВОСТІ СТВОРЕННЯ (ОНОВЛЕННЯ) ЦИФРОВИХ ТОПОГРАФІЧНИХ КАРТ ДЛЯ ФОРМУВАННЯ ОСНОВНОЇ ДЕРЖАВНОЇ ТОПОГРАФІЧНОЇ КАРТИ}

Метою статті є дослідження особливостей створення (оновлення) цифрових топографічних карт масштабу 1:50 000/1:10 000, які задовольнили б вимоги розроблення цілісної Бази топопографічних даних Основної державної топографічної карти масштабу 1:50 000. Методика. Основою дослідження $є$ аналіз можливостей застосування теорії баз даних і баз знань, міжнародних стандартів і специфікацій та методу векторизації. Результати. У статті досліджено особливості створення (оновлення) цифрової топографічної карти масштабу 1:50 000 для формування Основної державної топографічної карти, наведено основні етапи створення (оновлення) цифрових топографічних карт масштабу 1:50 000 території України з метою формування і ведення цілісної Бази топографічних даних загальнодержавного призначення, яку розміщено на Геопорталі для забезпечення актуальності єдиної цифрової топографічної основи завдяки веденню топографічного моніторингу місцевості та для розвитку Національної інфраструктури геопросторових даних в Україні. Також визначено і наведено вимоги до подання топографічних об'єктів, критеріїв відбору топографічних об' єктів та правила топологічних відношень між об’ єктами цифрових топографічних карт масштабу 1:50 000. Досліджено особливості забезпечення автоматизованого контролю якості оновлених цифрових топографічних карт. Зі створенням цілісної Бази топографічних даних Основної державної топографічної карти в умовах переходу від картографічної парадигми до геоінформаційної виникають нові вимоги до створення (оновлення) цифрових топографічних карт масштабу 1:50 000, а саме: створення просторових схем, описання внутрішньої конструкції моделей і правил цифрового опису геопросторових об’єктів, уніфікації каталогу об’єктів та їх атрибутів, а також правил топології між топографічними об’єктами для забезпечення топологічної узгодженості геометрії відповідно до стандартів і специфікацій серії національних стандартів України; створення програмного комплексу “Validate” для перевірки створених (оновлених) цифрових топографічних карт масштабу 1:50 000 для забезпечення автоматизованого контролю якості оновлених цифрових топографічних карт; створення нових віртуальних і асоційованих об’єктів на карті. Це забезпечить підвищення інтелектуального рівня створення геопросторових даних. Наукова новизна та практична значущість. Створена База топографічних даних Основної державної топографічної карти враховує використання нових віртуальних та асоційованих об'єктів, визначення критеріїв відбору і правил цифрового описання топографічних об'єктів, використання правил топологічних відношень між об'єктами цифрової топографічної карти, забезпечення автоматизованого контролю якості оновлених цифрових топографічних карт.

Ключові слова: Основна державна топографічна карта; цілісна База топографічних даних; геопортал; єдина цифрова топографічна основа; топологічні відношення; контроль якості; Національна інфраструктура геопросторових даних в Україні.

\section{Вступ}

Ухвалення Закону України "Про внесення змін до Закону України "Про топографо-геодезичну і картографічну діяльність” 11 лютого 2010 року та Порядку загальнодержавного топографічного і тематичного картографування, який було затверджено Постановою Кабінету Міністрів України № 661 від 4 вересня 2013 року, де-юре наблизило вирішення, але де-факто ще не вирішило проблему катастрофічного стану топографогеодезичної та картографічної діяльності через їі постійне недофінансування [Постанова Кабінету Міністрів України, 2013; Закон України, 1998]. Україна фак- тично не забезпечена актуальними державними топографічними картами всього масштабного ряду, оскільки роботи із загальнодержавного топографічного картографування території всієї країни довго не здійснювали [Карпінський Ю. і Лазоренко-Гевель Н., 2020; Лященко А., 2006; Карпінський Ю. і Лазоренко-Гевель Н., 2019]. В Україні досі немає Основної державної топографічної карти, яка б забезпечувала потреби органів державної влади та місцевого самоврядування, господарства, оборони, науки, освіти і громадян країни в актуальних топографічних картах, але вже не в класичному їх розумінні як цілісного картографічного твору 
багатоцільового призначення, а у вигляді баз топографічних даних (БТД) як сукупності взаємопов'язаних складноструктурованих геопросторових даних [Карпінський Ю. і Лазоренко-Гевель Н., 2020; Карпінський і Лященко А., 2006; Карпінський Ю. і ЛазоренкоГевель Н., 2018]. Бази топографічних даних, які створюють на основі цифрових топографічних карт: базових топографічних карт масштабу 1:10 000 та основних топографічних карт масштабів 1:50 000 і 1:100 000, становлять основу наборів базових геопросторових даних загальнодержавного рівня національної інфраструктури геопросторових даних (НІГД). Ухвалення Закону України "Про національну інфраструктуру геопросторових даних” 13.04.2020 р. та його імплементація підкреслили гостру необхідність і нагальність створення наборів базових геопросторових даних, які становлять уніфіковану цифрову координатно-просторову основу для виробництва, інтеграції та провадження іншої діяльності з різними наборами тематичних геопросторових даних [Закон України, 2020].

Дослідження пов'язано з виконанням українськонорвезького проєкту "Карти для сприяння належному управлінню землями в Україні”, реалізація якого розпочалася після підписання Угоди між Кабінетом Міністрів України та Урядом Королівства Норвегія про технічне та фінансове співробітництво від 18.10.2016 р. та Угоди для реалізації проєкту, що укладена між Державною службою України з питань геодезії, картографії та кадастру (Держгеокадастр) i Картографічною службою Королівства Норвегія (SK) від 28.02.2018 р. Крім зазначених вище учасників, до цього проєкту долучилось Міністерство оборони України. Укладено і підписано Меморандум про співпрацю між Міністерством оборони України та Державною службою України із питань геодезії, картографії та кадастру від 25 березня 2019 року. Відповідно до Угоди та Меморандуму буде створено (оновлено) цифрові топографічні карти масштабу 1:50 000, які використовуватимуться для створення цілісної Бази топографічних даних та Геопорталу (Держгеокадастр) і для підготовки карт до видання та введення в Базу даних картографічної інформації у середовищі геоінформаційної системи ArcGIS у військових частинах Центрального управління воєнно-топографічного та навігації Збройних сил України (рис. 1) [Карпінський, 2019].

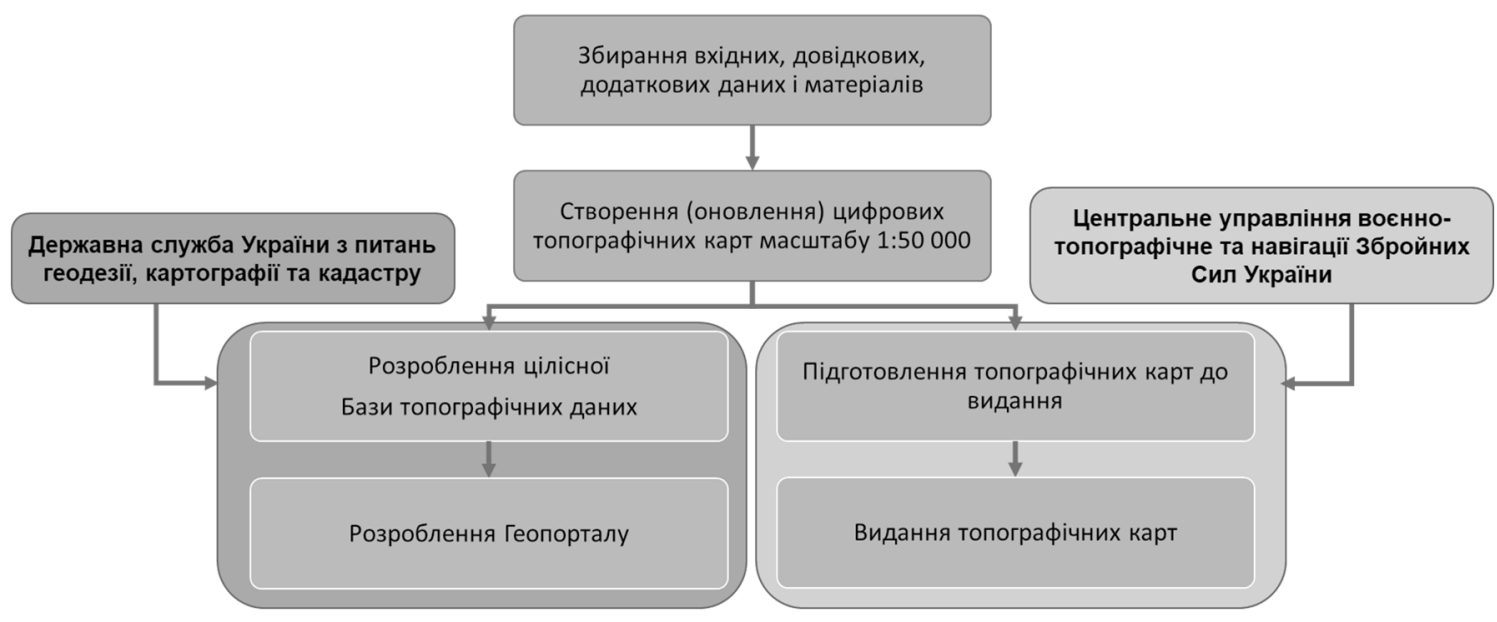

Рис. 1. Найважливіші етапи створення Основної державної топографічної карти

Вперше в Україні завдяки реалізації українськонорвезького проєкту створюється цілісна База топографічних даних Основної державної топографічної карти, яку розміщено на Геопорталі для забезпечення доступу до єдиної цифрової топографічної основи широкого кола користувачів. Вхідними даними до цілісної БТД є оновлені цифрові топографічні карти масштабу 1:50 000. Їхня головна особливість - вони гібридні, оскільки оновлення об' єктів із чіткими контурами (мережі доріг, вулиць, проїздів, кварталів і будинків, ліній електропередач (напругою більше ніж 35 кВ)) виконується із детальністю та точністю карти масштабу 1:10 000, а оновлення всіх інших об'єктів - 3 детальністю та точністю карти масштабу 1:50 000.
Оскільки оновлені цифрові топографічні карти масштабу 1:50 000/1:10 000 є вхідними даними для створення цілісної БТД та Геопорталу, то до їх створення (оновлення) ставлять нові сучасні вимоги, основні з яких - використання правил топологічних відношень між об'єктами.

\section{Мета}

Мета статті - дослідити особливості створення (оновлення) цифрових топографічних карт масштабу 1:50 000/1:10 000, які задовольнили б вимоги розроблення цілісної Бази топопографічних даних Основної державної топографічної карти масштабу 1:50 000. 
Особливості створення (оновлення) цифрових топографічних карт масштабу 1:50 000/1:10 000

Створення (оновлення) цифрових топографічних карт 1:50 000/1:10 000 Основної державної топографічної карти передбачає виконання таких основних етапів робіт:

1. Розроблення технічного завдання на надання послуг і редакційно-технічних вказівок. Створення бази топографічних даних “Основна державна топографічна карта”. Створення (оновлення) цифрових топографічних карт та Класифікатора картографічних даних на територію України за складом топографічної карти масштабу 1:50 000/1:10 000 з уніфікованим змістом (далі - Класифікатор) на основі нормативних документів [Закон України, 2020; Класифікатор інформації, 1998; Постанова Кабінету Міністрів України, 2013, Основні положення, 1999].

2. Збирання вхідних, довідкових, додаткових даних і матеріалів.

3. Підготовка вихідних, довідкових, додаткових даних і матеріалів.

4. Створення еталонної моделі цифрових топографічних карт масштабу 1:50 000/1:10 000 з метою апробації розроблених Редакційно-технічних вказівок. Крім того вона є взірцем, відповідно до якого повинні створюватися (оновлюватися) всі цифрові топографічні карти масштабу 1:50 000/1:10 000. Еталонна модель містить чотири аркуші, зведені по суміжних рамках.

5. Векторизація цифрових топографічних карт масштабу 1:50 000/1:10 000.

6. Проведення випробувань (контроль якості) оновлених цифрових топографічних карт масштабу 1:50 000/1:10 000.

Оскільки, як вже підкреслено вище в статті, оновлені цифрові топографічні карти масштабу 1:50 000/1:10 000 $\epsilon$ вхідними даними для цілісної БТД Основної державної топографічної карти, то ці стандартні етапи мають певні особливості, такі як: створення нових віртуальних та асоційованих об'єктів, визначення критеріїв відбору і правил цифрового описання топографічних об'єктів, використання правил топологічних відношень між об'єктами цифрової топографічної карти, забезпечення автоматизованого контролю якості оновлених цифрових топографічних карт.

\section{Створення нових віртуальних та асоційованих об'сктів}

Нові вимоги до оновлення цифрових топографічних карт 1:50 000/1:10 000 зумовлюють необхідність створення нових об'єктів, які не належать до об'єктів реального світу, так званих віртуальних (водотоки) й асоційованих об'єктів (квартали і межі населених пунктів.)

Для забезпечення побудови суцільної гідрографічної мережі в базу геоданих ArcGIS і Класифікатор додано новий об”єкт “Водоток” у набір даних “Гідрографія i гідротехнічні споруди", правила цифрового опису якого подано нижче:

- $\quad$ під час створення полігональних об'єктів гідрографії створюються віртуальні лінії водотоків за допомогою інструменту Production Centerline програмного забезпечення ArcGIS 10.5 (рис. 2);

- водотоки векторизуються по полігональних об' єктах гідрографії, що мають витік; наприклад, в озеpax без витоку лінію водотоку не відображають;

- у разі з'єднання двох лінійних водотоків на головному водотоці у місці з'єднання створюється вузлова точка;

- у ділянках з'єднання полігональних об'єктів основного русла та приток об'єкти розділяються по віртуальній лінії, що розмежовує гирло притоки та основне русло (рис. 3,4 );

- передбачено напрям векторизації об'єктів гідрографії від витоку до гирла, який повинен збігатися із напрямом течії (рис. 5);

- через полігональні об'єкти гідрографії без стоку віртуальні лінії водотоку не проводять (рис. 6);

- лінії об'єктів гідротехнічних споруд проводять по суміжній межі з об'єктами гідрографії (рис. 7);

Для коректної побудови кварталів виконують операції побудови буфера заданої величини залежно від типу вулиці. Під час векторизації кварталів уздовж магістральних вулиць створюють буферну зону завширшки 75 м, вулиці вирізають із кварталів буфером 10 м. Під час векторизації кварталів уздовж інших вулиць створюють буферну зону завширшки 65 м, вулиці вирізають із кварталів буфером 7 м.

Під час векторизації кварталів вручну - ширина кварталу вздовж магістральних вулиць становить 65 м, вздовж інших 62 м (рис. 8).

Векторне подання щільно та рідко забудованого кварталу з окремими будівлями в ньому подано на рис. 9.

Межі населених пунктів відображають на відстані від кварталів до 50 м. У межі населеного пункту входять території промислових та сільськогосподарських підприємств, не входять садові ділянки, суміжні із населеним пунктом, їх векторизують окремо.

Для коректного відображення межі населеного пункту необхідно створити буфер розміром до 50 метрів навколо всіх кварталів. Приклад векторизації межі населеного пункту подано на рис. 10.

Одному населеному пункту повинен відповідати один запис в атрибутивній таблиці, тобто якщо населений пункт дуже розосереджений і його можливо відобразити двома або більше полігонами, то полігони потрібно об'єднати, створивши мультиполігон.

\section{Визначення критеріїв відбору і правил цифрового опису топографічних об'сктів}

Для критеріїв відбору топографічних об'єктів складено відповідну таблицю, у якій визначено мінімальні розміри об'єктів на місцевості для масштабу 1:50 000/1:10 000 (табл. 1). 
Також встановлено допустимі середні квадратичні похибки просторового положення об'єктів цифрових топографічних карт для масштабу 1:50 000/1:10 000 (табл. 2).

Зауважимо, що детальність і точність сегмента “Дорожня мережа і дорожні споруди” передбачено для карти масштабу 1:10 000, що забезпечується використанням ортофотопланів масштабу 1:10 000 під час оновлення, тому в табл. 2 вказано допустимі середні квадратичні похибки векторних лінійних об'єктів від їх растрового зображення на ортофотоплані масштабу 1:10 000.

У табл. 2 відсутні допустимі середні квадратичні похибки просторового положення об'єктів цифрових топографічних карт 1:50 000/1:10 000 для таких класів об'єктів:

1) математичні елементи, елементи планової та висотної основи;

2) рельєф суші;

3) політико-адміністративний устрій, огорожі й окремі природні явища та об'єкти.

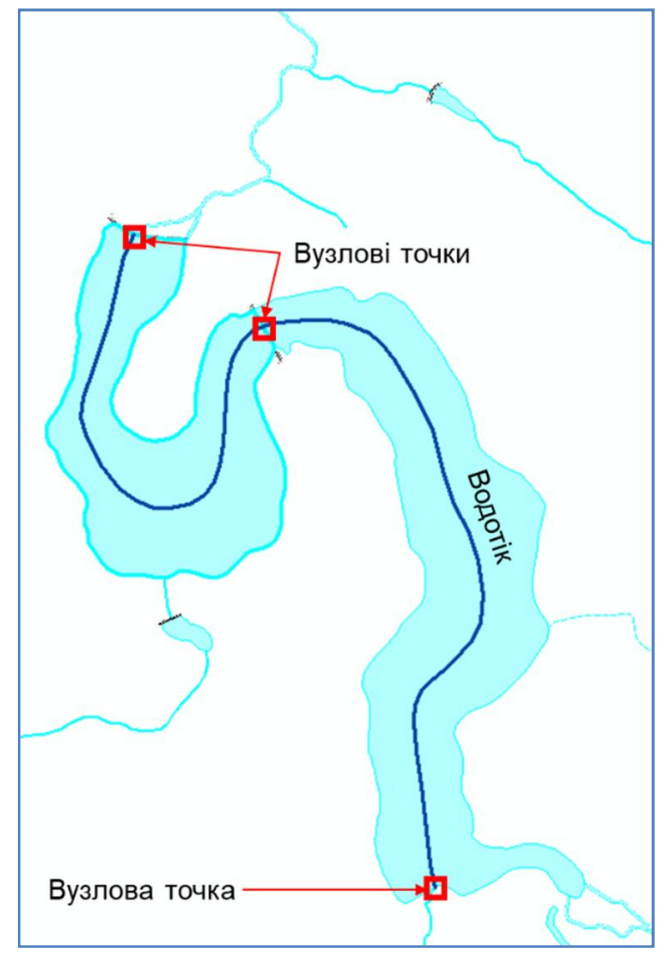

Рис. 2. Подання ліній водотоків

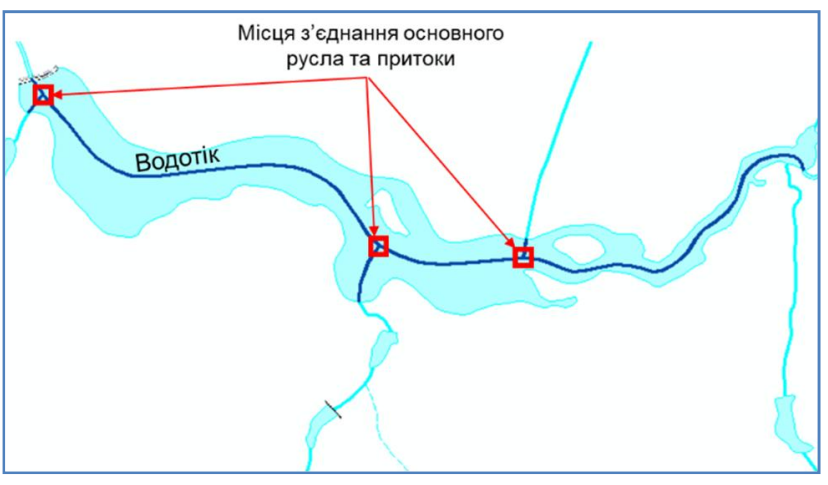

Рис. 3. 3'єднання основного русла та притоки

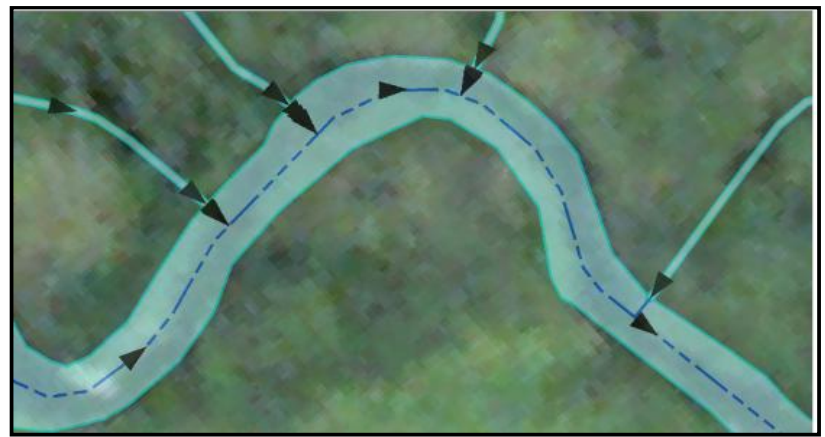

Рис. 4. Коректне відображення водотоків у місиях примикання лінійних об'єктів гідрографї до полігональних

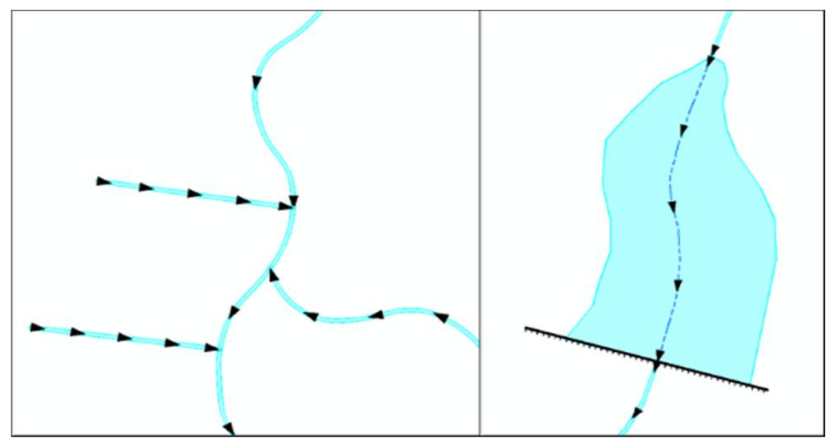

Рис. 5. Приклад напряму векторизаиї̈ об’єктів гідрографї

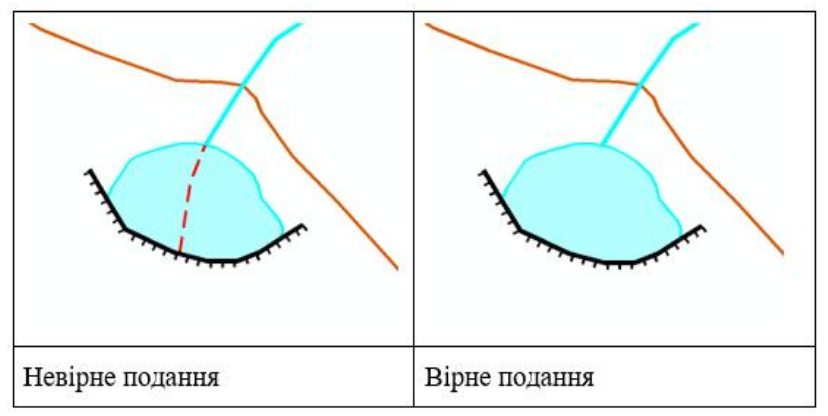

Рис. 6. Об’єкти гідрографії локального стоку

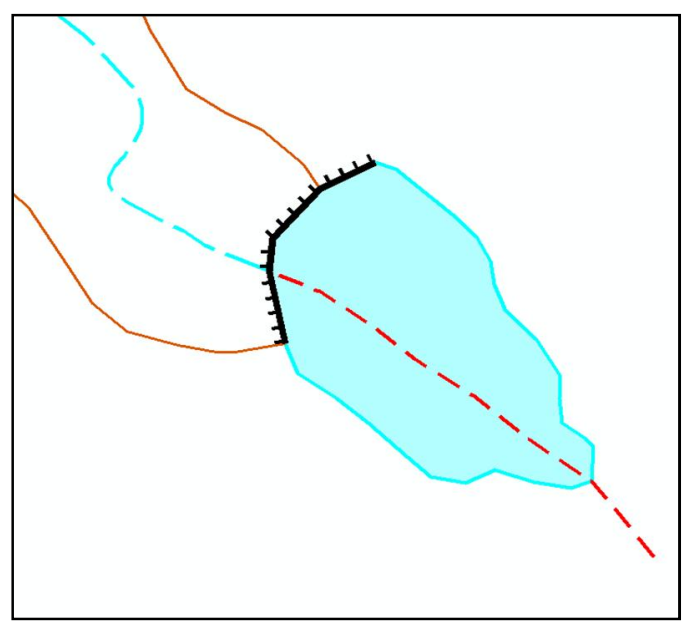

Рис. 7. Ізолінії рельєфу, гідротехнічної споруди та ставка проведено по суміжній межі 


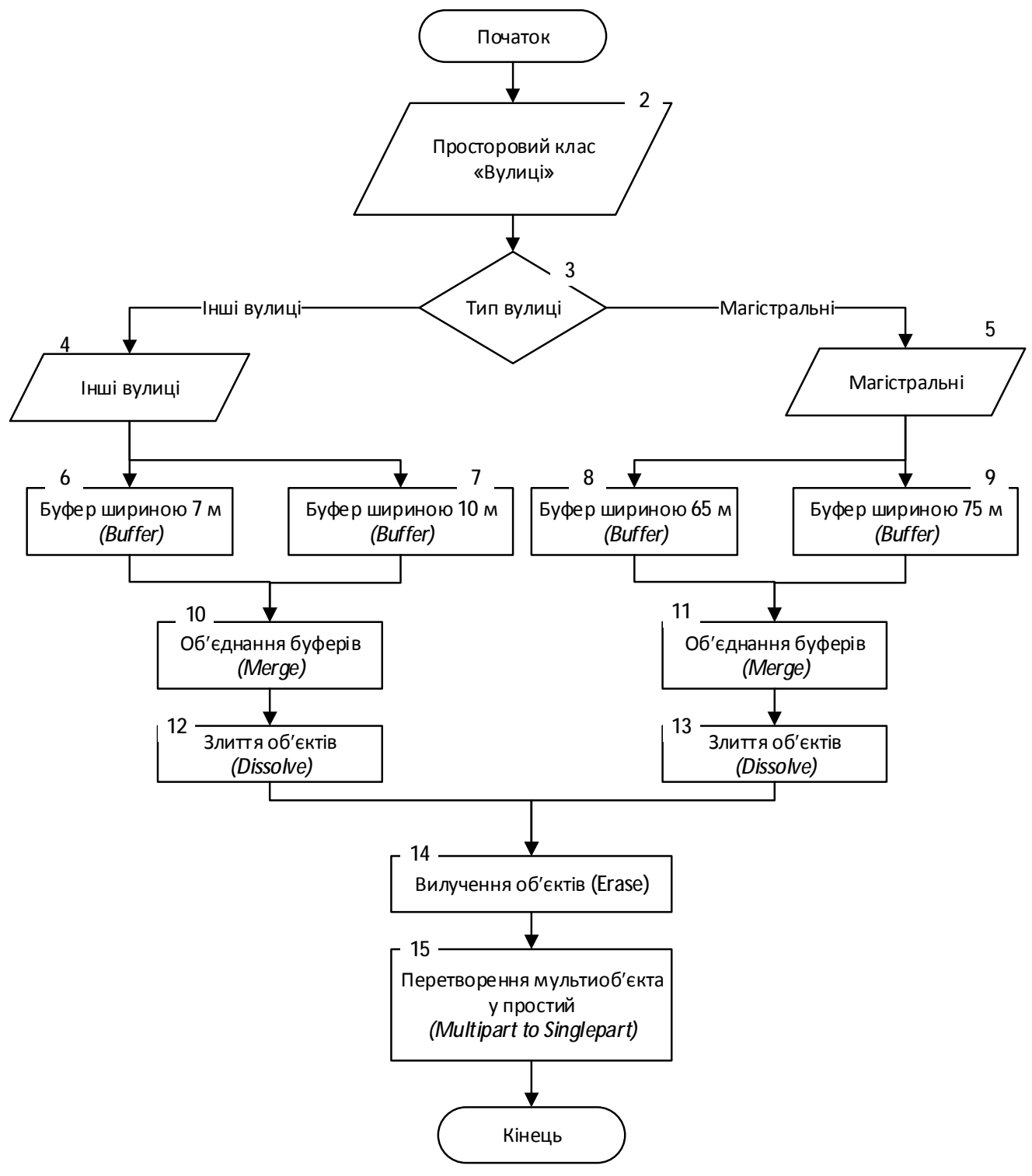

Рис. 8. Модель автоматичної побудови кварталів

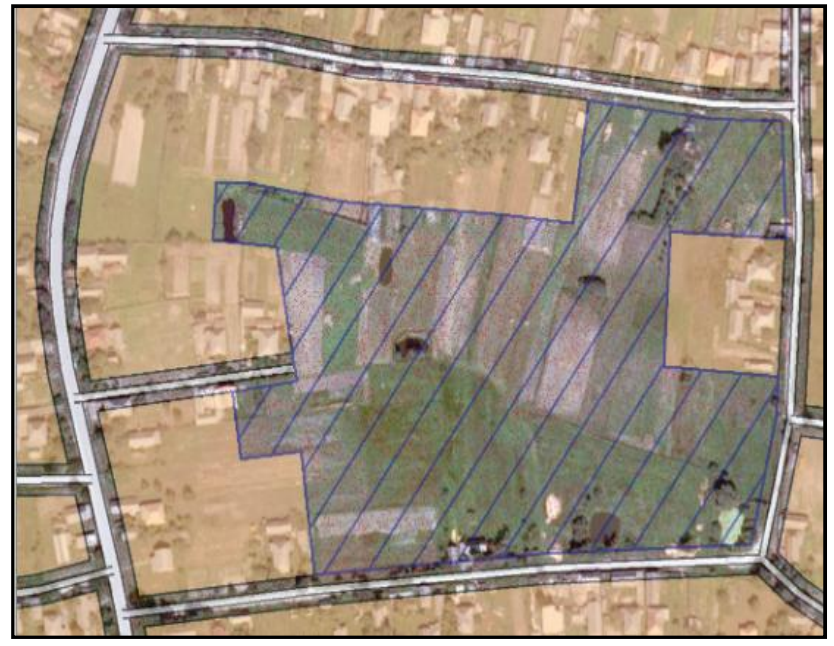

Рис. 9. Приклад векторизації щңільно та рідко забудованого кварталу з окремими будівлями в ньому

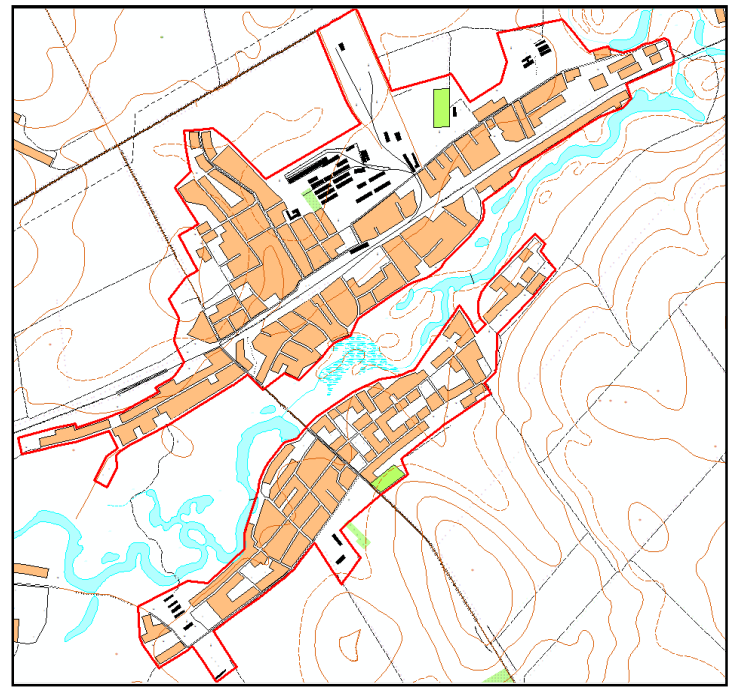

Рис. 10. Приклад векторизації межі населеного пункту 


\section{Критерії відбору топографічних об'сктів цифрових топографічних карт масштабу 1:50 000/1:10 000}

\begin{tabular}{|c|c|c|c|}
\hline $\begin{array}{l}\text { № } \\
\text { 3/ח }\end{array}$ & Назва топографічного об’єкта & $\begin{array}{c}\text { Мінімальний розмір } \\
\text { на місцевості }\end{array}$ & Інша ознака \\
\hline 1 & Озера та інші природні й штучні водойми & $0,0025 \mathrm{\kappa M}^{2}$ & \\
\hline 2 & Річки та струмки & $500 \mathrm{M}$ & \\
\hline 3 & Водосховища & $0,0025 \mathrm{\kappa M}^{2}$ & Водойми, у яких вода утримується греблею \\
\hline 4 & Греблі & $75 \mathrm{M}$ & \\
\hline 5 & Дамби & $150 \mathrm{M}$ & $\begin{array}{c}\text { відносна висота більше ніж } \\
\text { або дорівнює } 1 \text { м }\end{array}$ \\
\hline 6 & Дороги, вулиці & & $\begin{array}{c}\text { векторизують всі дороги, вулиці та проїзди } \\
\text { за ортофотопланами з детальністю } \\
\text { і точністю карти масштабу 1:10 } 000\end{array}$ \\
\hline 7 & Кар’єри & & $\begin{array}{c}\text { показують по контуру обробної площі, } \\
\text { дотримуючись напрямку шифрування } \\
\text { (за годинниковою стрілкою) }\end{array}$ \\
\hline 8 & $\begin{array}{c}\text { Залізниці вузькоколійні, монорейкові, } \\
\text { трамвайні колії, підвісні дороги, } \\
\text { фунікулери і бремсберги }\end{array}$ & $500 \mathrm{M}$ & \\
\hline 9 & Ділянки лісу та галявини в лісі & $0,025 \mathrm{KM}^{2}$ & \\
\hline 10 & Чагарникова рослинність & 0,025 км $^{2}$ & \\
\hline 11 & Піски & 0,025 км $^{2}$ & \\
\hline 12 & Болота & 0,062 км$^{2}$ & \\
\hline
\end{tabular}

\section{Допустимі середні квадратичні похибки просторового положення об'сктів цифрових топографічних карт масштабу 1:50 000}

\begin{tabular}{|c|c|c|c|}
\hline \multirow{3}{*}{$\begin{array}{l}\text { № } \\
\text { 3/П }\end{array}$} & \multirow{3}{*}{ Назва сегмента } & \multicolumn{2}{|c|}{ Допустимі середні квадратичні похибки } \\
\hline & & на рівнині & у гірських районах \\
\hline & & на місиевості & на місчевості \\
\hline 1 & Гідрографія і гідротехнічні споруди & $25 \mathrm{~m}$ & $37,5 \mathrm{~m}$ \\
\hline 2 & Населені пункти & $25 \mathrm{M}$ & $37,5 \mathrm{M}$ \\
\hline 3 & $\begin{array}{c}\text { Промислові, сільськогосподарські та } \\
\text { соціально-культурні об’ єкти }\end{array}$ & $25 \mathrm{M}$ & $37,5 \mathrm{M}$ \\
\hline 4 & Дорожня мережа і дорожні споруди & $\begin{array}{c}3 \text { м - автомобільні дороги із } \\
\text { твердим покриттям та залізниця } \\
5 \text { м - інші дороги }\end{array}$ & $10,0 \mathrm{M}$ \\
\hline 5 & Рослинний покрив та грунти & $50 \mathrm{M}$ & \\
\hline
\end{tabular}

Допустимі середні квадратичні похибки просторового положення об'єктів сегмента “Математичні елементи, елементи планової і висотної основи” залежать від класу пунктів Державної геодезичної мережі.

Для визначення допустимих середніх квадратичних похибок просторового положення об'єктів сегмента "Рельєф суші" необхідно використовувати стереомодель, а об'єкти сегмента "Політико-адміністративний устрій, огорожі і окремі природні явища та об'єкти” не є об'єктами місцевості.

\section{Використання правил топологічних відношень} між об'сктами цифрової топографічної карти

Векторизацію топографічних об'єктів виконують відповідно до встановлених топологічних правил між просторовими об'єктами, передбачених у середовищі ArcGIS. Особливості використання правил топології:

1) правила топології застосовують до просторових об'єктів того самого класу або до просторових відношень між об'єктами різних класів;

2) правила топології ураховують топографічний код просторового об'єкта; 
3) правила топологічних відношень враховують атрибутивні дані просторових класів, що дає змогу додавати винятки у правилах, тобто топологію відображають не повністю для усього класу, а з урахуванням умови щодо нього.

Сформульовано 141 правило топологічних відношень між просторовими об'єктами цифрової топографічної карти, що оновлюється:

- повинні бути більшими за кластерний допуск (Must Be Larger Than Cluster Tolerance);

- не повинні накладатися (Must Not Overlap);

- не повинні мати проміжків (Must Not Have Gaps);

- не повинні накладатися iз (Must Not Overlap With);

- повинні покриватися об'єктами іншого класу

(Must Be Covered By Feature Class Of);

- $\quad$ не повинні збігатися (Must Be Disjoint);

- $\quad$ не повинні накладатися самі із собою (Must Not Self-Overlap);

- не повинні перетинати самі себе (Must Not Self-Intersect);

- $\quad$ повинні суміщатися із (Must Be Covered By);

- межі повинні збігатися із (Boundary Must Be Covered By);

- не повинні містити висячих вузлів (Must Not Have Dangles).

Використання цих правил дає змогу контролювати коректність створення (оновлення), редагування просторових об'єктів з урахуванням топографічних кодів, атрибутивних характеристик просторових класів.

Для кожного аркуша цифрової топографічної карти заповнюють файл метаданих у редакторі метаданих ArcGIS відповідно до стандарту ISO 19139 "Географічна інформація. Метадані. Реалізація XML-схеми”, який використано в цьому програмному забезпеченні.

Редакційні роботи виконують на всіх етапах оновлення карт, починаючи із підготовчих робіт і закінчуючи редагуванням виправленого оригіналу.

Виконується зведення аркушів оновлених цифрових топографічних карт масштабу 1:50 000/1:10 000 по всіх рамках із суміжними оновленими аркушами карт.

\section{Забезпечення автоматизованого контролю}

\section{якості оновлених цифрових топографічних карт}

Проведення випробувань оновлених цифрових топографічних карт масштабу 1:50 000/1:10 000 виконується із застосуванням програмних засобів ArcGIS 10.5 і за допомогою програмного комплексу "Validate", розробленого державним підприємством "Науководослідний інститут геодезії і картографії”. Контроль якості створених (оновлених) цифрових топографічних карт масштабу 1:50 000/1:10 000 та ортофотопланів, виготовлених на основі супутникових знімань PlanetScope, здійснюється відповідно до: ДСТУ 2853-94. Підготовлення і проведення випробувань; ДСТУ 2851-94. Документування результатів випробування; Еталонної моделі цифрових топографічних карт масштабу 1:50 000.

Контроль якості оновленої цифрової топографічної карти здійснюється за всіма елементами змісту й оформлення, для того щоб перевірити забезпечення однотипності кодування і подання однотипних об'єктів, зведення між суміжними аркушами.

Контроль якості оновленої цифрової топографічної карти складається із таких етапів: перевірка комплектності матеріалів, перевірка назв файлів, перевірка елементів якості топографічних даних та якості метаданих.

До основних елементів якості топографічних даних та якості метаданих належать: повнота даних, логічна узгодженість, якість метаданих, точність планового положення топографічних об' єктів. Логічну узгодженість топографічних даних оцінюють за показниками:

- концептуальна узгодженість - відповідність правилам концептуальної схеми та структурі й відношенням відповідно до вимог створення (оновлення) цифрових топографічних карт [Andrew U. Frank, 1988; Jakobsson A. 2006; Hampe M., 2004, Lüscher, P., 2011; L. Tiina Sarjakoski, 1997];

- доменна узгодженість - відповідність значень атрибутів області допустимих значень, узгодженість за форматом - ступінь відповідності накопичених даних фізичній структурі набору даних;

- топологічна узгодженість - коректність подання закодованих топологічних характеристик геометричних об'єктів набору даних. Топологічна узгодженість визначається як для геометричних моделей топографічних об' єктів одного типу, так і для геометричних моделей топографічних об'єктів різних типів.

Допустимі відхилення планового положення об' єктів та контурів місцевості відносно їх растрового зображення (ортофотоплану масштабу 1:10 000) становлять: для чітких контурів: дороги, вулиці, канали - 3 м, польових доріг - 5 м.

Виконавши контроль якості створених (оновлених) цифрових топографічних карт масштабу 1:50 000/1:10 000, складають Протокол випробувань оновленої цифрової топографічної карти масштабу 1:50 000/1:10 000.

Перевірку за правилами топологічних відношень між просторовими об'єктами оновлюваної цифрової топографічної карти виконують за допомогою програмного комплексу "Validate", який розроблено мовою візуального моделювання Model Builder у програмному середовищі ArcGIS 10.5 для перевірки логічної узгодженості, наявності та наповненості метаданих. 


\section{Висновки}

Створення цілісної Бази топографічних даних Основної державної топографічної карти в умовах переходу від картографічної парадигми до геоінформаційної зумовлює нові вимоги до створення (оновлення) цифрових топографічних карт масштабу 1:50 000, а саме:

- створення просторових схем, описання внутрішньої конструкції моделей і правил цифрового описання геопросторових об'єктів, уніфікації каталогу об'єктів та їх атрибутів, а також правил топології між топографічними об'єктами для забезпечення топологічної узгодженості геометрії відповідно до стандартів і специфікацій: серії національних стандартів України ДСТУ ISO 19100 "Географічна інформація/ Геоматика”, прийнятих методом прямого підтвердження міжнародних стандартів цієї серії та ДСТУ 8774:2018 "Географічна інформація. Правила моделювання геопросторових даних", комплексом стандартів організацій України "База топографічних даних";

- створення програмного комплексу "Validate" для перевірки створених (оновлених) цифрових топографічних карт масштабу 1:50 000 для забезпечення автоматизованого контролю якості оновлених цифрових топографічних карт;

- створення нових віртуальних і асоційованих об'єктів на карті.

Це забезпечить підвищення інтелектуального рівня створення геопросторових даних. Створені (оновлені) цифрові топографічні карти окремими зведеними аркушами карт масштабу 1: 50 000/1:10 000 у Державній геодезичній референцній системі координат УСК-2000 в проекції Гаусса - Крюгера у відповідній шестиградусній зоні в прийнятій державній розграфці топографічних карт у масштабі 1:50 000/1:10 000 будуть використовуватися для:

- формування Основної державної топографічної карти як сукупності взаємопов' язаних структурованих геопросторових даних у базі топографічних даних та розміщення iï на Геопорталі Основної державної топографічної карти для забезпечення актуальності єдиної цифрової топографічної основи веденням топографічного моніторингу місцевості та для розвитку Національної інфраструктури геопросторових даних в Україні;

- підготовка цифрових топографічних карт до видання та введення в Базу даних картографічної інформації у середовищі геоінформаційної системи ArcGIS у військових частинах Центрального управління воєнно-топографічного та навігації Збройних сил України.

\section{Література}

Закон України "Про топографо-геодезичну і картографічну діяльність” від 23 грудня 1998 року № 353-XIV.

Закон України "Про національну інфраструктуру геопросторових даних" від 13 квітня 2020 року № 554-IX.

Карпінський Ю. О., Лазоренко-Гевель Н. Ю. (2019). Архітектура державної топографічної карти. Всеукраїнська науково-практична конференція “Картографічне моделювання та географічні інформаційні системи" (3-5 жовтня 2019 року). Львів: Нац. ун-т “Львівська політехніка", С. 11-14.

Карпінський Ю. О., Лященко А. А. (2006). Стратегія формування національної інфраструктури геопросторових даних в Україні. К.: НДІГК, 108 с.: іл. (Сер. "Геодезія, картографія, кадастр").

Карпінський Ю. О. Лазоренко-Гевель Н. Ю. (2018). Методи збирання геопросторових даних для топографічного картографування. Сучасні досягнення геодезичної науки і виробництва: зб. наук. праць, Вип. I(35), С. 204-211. [Електронний ресурс]. Режим доступу: http://gki.com.ua/ua/metodizbirannja-geoprostorovih-danih-dlja-topografichnogokartografuvannja.

Класифікатор інформації, яка відображається на топографічних картах масштабів 1:10 000, 1:25 000, 1:50 000, 1:100 000, 1:200 000, 1:500 000, 1:1000 000: затверд. начальник Головного управління геодезії, картографії та кадастру при Кабінеті Міністрів України 1998 р. і погодж. з начальником Центрального топографічного управління Генерального штабу Збройних сил України.

Основні положення створення та оновлення топографічних карт масштабів 1:10 000, 1:25 000, 1:50 000, 1:100 000, 1:200 000, 1:500 000, 1:1 000 000: затвердж. наказом Головного управління геодезії, картографії та кадастру України № 156 від 31.12.1999 р. і погодж. з Воєнно-топографічним управлінням Генерального штабу Збройних сил України.

Постанова Кабінету Міністрів України "Про затвердження Порядку загальнодержавного топографічного і тематичного картографування" від 4 вересня 2013 p. № 661.

Andrew U. Frank. (1988). Requirements for a database management system for a GIS. Photogrammetric Eng. \& Remote Sensing, vol. 54, No. II, 1557-1564, Nov. 1988. Retrieved from: https://www.asprs.org/ wp-content/uploads/pers/1988journal/nov/1988_nov_ 1557-1564.pdf

Hampe M., Sester M. and Harrie L. (2004). Multiple Representation Databases To Support Visualisation On. Proceedings of the XXth ISPRS Congress. 
Retrieved from: https://www.researchgate.net/ publication/2933118_Multiple_Representation_Datab ases_To_Support_Visualisation_On (09.01.2020).

Jakobsson, A. (2006). On the Future of Topographic Base Information Management in Finland and Europe: doctoral dissertation. Helsinki University of Technology, http://lib.tkk.fi/Diss/2006/isbn9512282062/ isbn9512282062.pdf, 180 p +annexes.

Karpinskyi Yu., \& Lazorenko-Hevel N. (2020). Topographic mapping in the National Spatial Data Infrastructure in Ukraine. E3S Web of Conferences. 171, 1-6. https://doi.org/10.1051/e3sconf/ 202017102004.

Lazorenko-Hevel, N. and Kin, D. (2019). The edge matching method of digital topographic maps in the scale of 1:50 000 for creation the main state topographic map. Engineering Geodesy, 67, 56-66. 10.32347/0130-6014.2019.67.56-66.
Lüscher, P. (2011). Characterising urban space from topographic databases: cartographic pattern recognition based on semantic modelling. Zurich Open Repository and Archive, University of Zurich. Retrieved from: https://www.zora.uzh.ch/id/eprint/ 164120/1/20121448.pdf.

L. Tiina Sarjakoski (1997) Multiple Representation and Generalization of Geo-Databases for Topographic Maps. Doctoral dissertation, Helsinki University of Technology. Publications of the Finnish Geodetic Institute, N:o 124, Kirkkonummi, 229 p. Retrieved from: https://www.researchgate.net/publication/ 269278367_Multiple_Representation_and_Generaliza tion_of_GeoDatabases_for_Topographic_Maps_Doct oral_dissertation_Helsinki_University_of_Technolog yPublications_of_the_Finnish_Geodetic_Institute_No _124_Kirkkonumm.

\section{N. LAZORENKO-HEVEL ${ }^{1}$, YU. KARPINKYI ${ }^{2}$, D. KIN ${ }^{1}$}

${ }^{1}$ Department of Geoinformation system and photogrammetry, Kyiv National University of Construction and Architecture, 31, Povitroflotsky Av., Kyiv, 03037, Ukraine; e-mail: nadiialg@gmail.com, kondanil@gmail.com.

${ }^{2}$ Research Institute of Geodesy and Cartography 69, Velika Vasylkivska Str., Kyiv, 03150, Ukraine; e-mail: karp@ gki.com.ua

\section{CREATION (UPDATING) DIGITAL TOPOGRAPHIC MAPS FOR THE FORMING THE MAIN STATE TOPOGRAPHIC MAP}

Purpose. The purpose of the article is to research the peculiarities of creation (updating) of digital topographic maps at the scale of 1:50 000/1:10 000 which would satisfy the requirements for the development of the seamless Topographic Database of the Main State Topographic Map at the scale of 1:50 000.

Methodology. The basis for the research is the analysis of the possibilities of applying the theory of databases and knowledge bases, International Standards and specifications and vectorization method.

Results. The article examines the peculiarities of creation (updating) digital topographic maps of the scale 1:50 000 for the formation of the Main State Topographic Map of Ukraine for the purpose of the creation and maintain the seamless topographic database for national needs, which is located on the Geoportal to ensure the relevance of a single digital topographic basis by topographical monitoring of the territories and for the development of the National Spatial Data Infrastructure in Ukraine. The rules of topological relations between features of the digital topographic maps of the scale 1:50 000 are also defined and given. The peculiarities of providing automated quality control of updated digital topographic maps are investigated. The creation of the seamless Topographic Database of the Main State Topographic Map in the conditions of transfer the cartographic paradigm to geoinformation creates new requirements for the creation (updating) of digital topographic maps of the scale 1:50 000/10 000: creation of spatial schemes, description of the internal design of models and rules of digital description of geospatial features, unification of the features catalog and their attributes, as well as rules of topology between topographic features to ensure topological consistency of geometry in accordance with standards and specifications; creation of the "Validate" software package for checking of created (updated) digital topographic maps at a scale of 1:50 000/10 000 to ensure automated quality control of updated digital topographic maps; creation of new virtual and associated features in the TDB of the Main State Topographic Map. This will increase the intellectual level of geospatial data creation. Scientific novelty and practical significance. The creation of the Main Topographic Map Topographic Database takes into account the use of new virtual and associated features, the use of rules of topological relations between digital topographic map features, providing automated quality control of updated digital topographic maps. 
Key words: National Spatial Data Infrastructure (NSDI); topographic mapping; Main State Topographic Map; seamless Topographic Database; topological relations; quality control.

\section{References}

Andrew U. Frank. (1988). Requirements for a database management system for a GIS. Photogrammetric Eng. \& Remote Sensing, Vol. 54, No. II, 1557-1564, Nov. 1988. Retrieved from https://www.asprs.org/wp-content/uploads/pers/1988journal/ nov/1988_nov_1557-1564.pdf

Basic provisions for creating and updating topographic maps at scales 1:10 000, 1:25 000, 1:50 000, 1:100 000, 1:200 000, 1:500 000, 1:1 000000 (Approved by the order of the Main Department of Geodesy, Cartography and Cadastre of Ukraine No. 156 dated 31.12.1999 and agreed with the Military Topographic Directorate of the General Staff of the Armed).

The classifier of information displayed on topographic maps of scales 1:10 000, 1:25 000, 1:50 000, 1:100 000, 1:200 000, 1:500 000, 1:1000 000 (Approved by the Head of the Main Department of Geodesy, Cartography and Cadastre under the Cabinet of Ministers of Ukraine in 1998 and agreed with the Military Topographic Directorate of the General Staff of the Armed).

Jakobsson, A. (2006). On the Future of Topographic Base Information Management in Finland and Europe. Doctoral dissertation. Helsinki University of Technology. Retrieved from: http://lib.tkk.fi/Diss/2006/isbn9512282062/ isbn9512282062.pdf, $180 \mathrm{p}$ +annexes.

Hampe M., Sester M. and Harrie L. (2004). Multiple Representation Databases To Support Visualisation On. Proceedings of the XXth ISPRS Congress. Retrieved from: https://www.researchgate.net/publication/ 2933118_Multiple_Representation_Databases_To_Support_Visualisation_On (09.01.2020).

Karpinskyi, Yu. and Lazorenko-Hevel, N. (2018) Application of topographic plans in the conditions of the development of national spatial data infrastructure. Mistobuduvannya ta terytorial'ne planuvannya, 68, 712-724 Retrieved from http://nbuv.gov.ua/UJRN/MTP_2018_68_85.

Karpinskyi, Yu. and Lazorenko-Hevel, N. (2020). Topographic mapping in the National Spatial Data Infrastructure in Ukraine. E3S Web of Conferences. 171, 1-6. https://doi.org/10.1051/e3sconf/202017102004.

Karpinkyi Y. (2019). Architecture of the main state topographic map / Yurii Karpinkyi, Nadiia Lazorenko-Hevel // Kartohrafichne modeliuvannia ta heohrafichni informatsiini systemy : zbirnyk materialiv vseukrainskoi naukovopraktychnoi konferentsii, 3-5 zhovtnia 2019 roku, Lviv. Lviv: Vydavnytstvo Lvivskoi politekhniky, pp. 11-14.

Karpinskyi, Yu. O., \& Liashchenko, A. A. (2006). Strategy for the formation of the national infrastructure of geospatial data in Ukraine. Kyiv: NDIHK, 108 p. (in Ukrainian).

The Law of Ukraine "On the National Spatial Data Infrastructure" (bill No. 2370), 13.04.2020. Retrieved from: http://w1.c1.rada.gov.ua/pls/zweb2/webproc34?id=\&pf3511=67268\&pf35401=525603 (09.01.2020).

The Law of Ukraine "On topographic-geodetic and cartographic activity" (bill No. 353-XIV), 23.12.1998. Retrieved from: https://zakon.rada.gov.ua/laws/show/353-14\#Text (09.01.2020).

Lüscher, P. (2011) Characterising urban space from topographic databases: cartographic pattern recognition based on semantic modelling. Zurich Open Repository and Archive, University of Zurich. Retrieved from: https://www.zora.uzh.ch/id/eprint/164120/1/20121448.pdf.

Lazorenko-Hevel, N. and Kin, D. (2019). The edge matching method of digital topographic maps in the scale of 1:50 000 for creation the main state topographic map. Engineering geodesy, 67, 56-66. 10.32347/0130-6014.2019.67.56-66.

Resolution of the Cabinet of Ministers of Ukraine "On Approval of the Procedure for National Topographic and Thematic Mapping" of September 4, 2013. No. 661.

L. Tiina Sarjakoski (1997) Multiple Representation and Generalization of Geo-Databases for Topographic Maps: doctoral dissertation, Helsinki University of Technology. Publications of the Finnish Geodetic Institute, N:o 124, Kirkkonummi, 229 p. Retrieved from: https://www.researchgate.net/publication/269278367_ Multiple_Representation_and_Generalization_of_GeoDatabases_for_Topographic_Maps_Doctoral_dissertation_Helsink i_University_of_TechnologyPublications_of_the_Finnish_Geodetic_Institute_No_124_Kirkkonumm. 